\title{
War and Women's Work: Evidence from the Conflict in Nepal
}

\author{
Nidhiya Menon, Brandeis University
}

Yana van der Meulen Rodgers, Rutgers University

Version: November 24, 2010

\begin{abstract}
In a study of the effect of war on women's work, this paper examines how Nepal's 1996-2006 civil conflict affected women's decisions to engage in employment. Using three waves of Nepal Demographic and Health Survey, we employ a difference-in-difference approach to identify the impact of war on women's employment decisions. Results indicate that as a result of the Maoist-led insurgency, women's employment probabilities were substantially higher in 2001 and 2006 relative to the outbreak of war in 1996. These employment results also hold for self-employment decisions, and they hold for smaller sub-samples that condition on husband's migration status and women's status as widows or household heads. Robustness checks of the difference-in-difference estimates based on alternative empirical methods provide substantial evidence that women's likelihood of employment increased as a consequence of the conflict.
\end{abstract}

Corresponding author: Yana van der Meulen Rodgers, Women's and Gender Studies Department, Rutgers University, New Brunswick, NJ 08901. Tel 732-932-9331, fax 732-9321335, email yrodgers@ @rci.rutgers.edu. Contact information for Nidhiya Menon: Department of Economics \& IBS, MS 021, Brandeis University, Waltham, MA 02454-9110. Tel 781-736-2230, fax 781-736-2269, email nmenon@brandeis.edu. We thank Josh Angrist for initial discussions on research design, and Lakshmi Iyer and Quy-Toan Do for sharing their Nepal conflict data. Thanks also to participants at Brandeis, Wellesley, and the 2010 World Bank workshop on Gender and Conflict and to our discussants at this workshop, Hasan Zaman and Quy-Toan Do. This research is supported by the World Bank. 


\section{Introduction}

Nepal's civil war, which started in 1996, resulted from a movement by Maoist insurgents to take advantage of the growing dissatisfaction among the people, especially those living in rural areas, with the lack of economic reforms they had expected from a new democraticallyelected government. Beginning in the western region, the conflict engulfed a large part of the country in a relatively short period of time. The conflict ended in 2006 when, following a prolonged state of emergency and absolute power by the monarch, the Maoist party succeeded in brokering a peace agreement that led to a new constitution and the establishment of a people's republic. During this ten-year period, the conflict led to immense suffering in terms of thousands of deaths and injuries. It also caused major economic disruption and placed tremendous hardships on the local population. These devastating consequences have led experts to rank Nepal's "People's War" as one of the most intense civil conflicts in the world in recent times (Murshed and Gates 2005).

The goal of this research is to examine how civil war in Nepal affected women's decisions about participating in market work. In particular, women may join the labor force in an "added worker" effect as they try to compensate for declines in household income caused by losses in their husbands' earnings due to war-related disruptions, departures, injuries, or deaths. Evidence from a number of industrialized country studies suggests that the added worker effect was strong during the World Wars and the Great Depression, but it has become less important over time as women's status in the labor market improved (e.g. Finegan and Margo 1994; PrietoRodriguez and Rodriguez-Gutierrez 2003). However, much of the improvement in women's status is limited to the labor markets of more developed economies. A small but growing number of studies for developing countries point to a substantial added worker effect, especially in times 
of financial crisis (e.g. Parker and Skoufias 2004). In such times, households in developing countries cope with declines in income by sending household members to seek employment in paid work (Jones et al. 2009). Furthermore, cross-country evidence indicates that women's labor supply, particularly in Asia and Latin America, is counter-cyclical. That is, women engage in more employment and self-employment when aggregate income falls (Bhalotra and UmanaAponte 2010).

This study employs a difference-in-difference approach to identify the impact of war on women's employment decisions, using data from the Nepal Demographic and Health Survey from 1996, 2001, and 2006. These data are used to test the hypothesis that with the displacement of male workers as a result of the Maoist insurgency, women's employment decisions exhibited an added worker effect. We find strong evidence that as compared to 1996, the year in which conflict started in Nepal, women's employment probabilities are significantly higher in 2001 and 2006 as a result of the conflict. These trends are evident in patterns of self-employment work as well. These employment results for women also hold in regressions that condition on husband's migration status and women's status as widows or household heads. The results are interpreted as evidence of a labor supply rather than a labor demand effect. Women needed to work to support their households, rather than being enticed to enter the market because of the creation of new economic opportunities. The analysis includes robustness checks of the difference-indifference estimates and demonstrates that even with the use of alternative empirical methods, there is substantial evidence that women's likelihood of employment increased as a consequence of the conflict.

\section{Conflict Background and Economic Context}


Nepal's civil war, also known as the "People's War," erupted in 1996 when members of the Communist Nepal-Maoist party struck a police station in Rolpa, a district in the western region of Nepal. The motivation behind the attack and the subsequent ten years of insurgency had several origins (Deraniyagala 2005; Murshed and Gates 2005; Sharma 2006). Anger by members of lower castes and lower-status ethnic groups against the elite for long periods of landlessness and deprivation helped to instigate and fuel the conflict. Other sources of the insurgency included overall poverty and the lack of economic development, as well as dissatisfaction against the government for targeting Maoist activists. Regardless of the exact source, the Maoist party used the discontent to further their objectives of weakening and eliminating the monarchy. From 1996 onwards, the Maoists used a variety of tactics to achieve their goals. Primary among these were attacks on army bases, police posts, government officials, and banks. At the height of the conflict, the Maoists controlled most rural areas of the country. In 2006, a republic of the people was established with a new Constituent Assembly and constitution. By 2008, the Maoists held the majority of seats in the new Constituent Assembly and their leader was elected the first Prime Minister of the new republic.

Nepal's geographical terrain served as an important determinant of the intensity and likelihood of civil war violence. Since government forces outnumbered the insurgents, insurgent forces depended on mountainous and forested terrain to help them hide and maneuver. Economic development also played a role since the Maoists could find greater support for their cause among the poor and disenfranchised. These arguments are supported in Do and Iyer (2010) who find conflict-related deaths were substantially higher in districts with higher poverty, and in districts characterized by higher elevation and forest coverage. Their results indicate that geographic conditions explain approximately 25 percent of the variation across districts in 
conflict intensity, with the pre-1996 rate of poverty at the district level also serving as a positive predictor of conflict intensity. The relationship between the intensity of violence and Nepal's geography and terrain is also supported in Bohara et al. (2006).

The civil war entailed enormous social costs. The death toll reached over 13,300, with about two thirds of those deaths being caused by government forces and the remaining one third caused by Maoist insurgents (INSEC 2010). As shown in Figure (1), the conflict-related deaths increased sharply in 2002, an escalation that coincided with Prime Minister's announcement of a state of emergency and his mobilization of the Royal Nepal Army to combat the insurgents. In addition, the drawn-out conflict caused substantial destruction to the country's infrastructure as well as the postponement of new projects. This crippling of the country's infrastructure not only restricted access to education and health systems, it also stifled economic growth and development.

\section{Insert Figure 1 Here}

That conflict imposes economic shocks and curtails development is supported by evidence in Ra and Singh (2005). This study shows that the decline in development expenditures stemming from conflict had strong negative effects on the growth of gross domestic product. In particular, for a $4.2 \%$ decline in development expenditures, Nepal would lose $1.7 \%$ of annual growth in GDP between the 2005-2009 fiscal years. That said, the decline in GDP growth is likely to be an underestimate as other factors such as destruction of infrastructure, disruption of activities, lower private investment, and displacement of people are not taken into account in the specifications. Such effects are incorporated in our estimations through the inclusion of controls for region and year. 
Nepal's civil war also resulted in a disproportional increase in consumption by households with relatively more land, with the landless or those with extremely small amount of land suffering from relative deprivation. Such increases in inequality help to explain the rise in Maoist recruitment activities, since such activities were relatively more pronounced in districts where inequality had increased significantly (Macours, 2010). We control for the effects of poverty and inequality by including measures specific to these variables in our models.

Furthermore, existing migration rates increased to some extent as a consequence of the civil war (MHP/NE/MI 2007). This migration caused numerous married couples to live apart for extended periods. Hence conflict-induced mortality of men combined with substantial male migration left a growing proportion of women to manage their households. Our calculations based on the Nepal DHS data indicate that during the conflict period, the proportion of women whose husbands had migrated grew over time, as did the proportion of women who reported themselves as their household's head. As shown in Panel A of Figure 2, 16 percent of all evermarried women reported that their husbands had migrated in 1996; this proportion had risen by about ten percentage points by the end of the conflict period. Another 5 percent of all evermarried women reported the loss of their husbands due to death, divorce, or separation; this proportion did not change much during the conflict period. Closely related, Panel B shows that the proportion of women who reported themselves as the household head more than doubled during the conflict period, from seven percent to 15 percent. While most of this increase occurred due to the migration of husbands, some growth occurred due to the death, divorce, separation, and incapacitation of husbands.

Insert Figure 2 Here 
The decade-long conflict is likely to have had an impact on women's employment probabilities because of the disruptions to family life. Not only did the conflict cause widespread mortality, especially among men, it also led to an increase in family separation rates and in disability rates among husbands. Another channel through which conflict may have induced greater labor force participation for women is through displacement of men in the household. As noted in Seddon and Adhikari (2003), mainly men left home on a temporary basis seeking work and security. It was not common for entire families to move as women often remained behind to look after the household's plots of land. These are the various channels through which conflict may have induced additional work for women as took on the role of sole bread-winners in their family.

Existing literature is not conclusive that a greater proportion of Nepalese women did in fact enter the labor force as a result of the conflict-induced changes in household composition and income. Assessment results reported in the World Bank (2004) indicate that the absence of husbands and their income led to a dramatic increase in women's household and farm work burdens, but the findings do not specify whether this increased work burden coincided with higher rates of employment. The income effect from remittances sent home by migrant husbands could have acted as a disincentive for women to become employed. Also, the departure of a spouse who contributed to household farm production may have put more pressure on women to increase their hours of work in subsistence farming. Both of these arguments help to explain Lokshin and Glinskaya's (2009) finding of an inverse relationship between men's migration and women's market work participation in Nepal in 2004. Further evidence in Menon (2009) indicates that given the dominance of agriculture as the main source of employment, and the fact that agriculture is subject to the variability of rainfall, households in rural Nepal strive to 
diversify their sources of income by investing in off-farm work such as non-agricultural wage or self-employment. Since non-agricultural wage employment tends to be dominated by men and is relatively less attractive for women in rural Nepal, the added worker effect in this context may have manifested itself in the guise of more self-employment being undertaken by women. In order to account for effects on self-employment that may differ from overall employment, this study estimates self-employment impacts separately.

\section{Grouping of Districts into Conflict and Non-Conflict Sub-Regions}

Our research design centers on the idea that regions in Nepal characterized by greater forest coverage, higher elevations, more rainfall, and fewer roads were more conducive to guerilla activity and conflict. Following the strategy developed in Angrist and Kugler (2008), we classified regions based on geography from a time period that precedes the conflict (1994). Geographical measures from a pre-conflict time period were used as instruments to approximate conflict intensity from 1996 to 2006. In a "first stage" procedure, we tested the predictive power of these instruments in explaining conflict intensity, where conflict intensity was measured by the total number of casualties due to state and Maoist action from 1996 to $2006 .{ }^{1}$ Note that the Nepal employment and conflict data we used divided Nepal into 75 districts, which were further classified into five regions (Eastern, Central, Western, Mid-Western, and Far-Western) and three categories of physical terrain (Mountain, Hill, and Terai grasslands). In order to facilitate parameter estimation in the subsequent regressions, we aggregated the 75 districts into 15 subregions (the five regions interacted with the three types of terrain).

Conflict measures cannot be used directly in the estimations since they are likely to be co-determined with other variables that might affect women's employment. For example, subregions with higher rates of poverty also had more intense conflict (Do and Iyer 2010). We 
hypothesize that geographical measures from a pre-conflict time period provide the exogenous variation required to identify the effect of conflict on women's work. To test this hypothesis, we used the conflict and geographical indicators from Do and Iyer (2010), supplemented with additional geographical and weather data on Nepal from Sharma and Subedy (1994). In the first stage, the number of state-caused and Maoist-caused deaths from 1996 to 2006 was regressed on four indicators of geographical status and two indicators of weather status. Indicators of geographical status include the proportion of a sub-region that is forested, altitude of the subregion as a proxy for mountainous/hilly territory, the number of major rivers in a sub-region normalized by area, and the total length of the road network normalized by the area of the subregion. Indicators of weather-related status include average annual rainfall normalized by area of the sub-region and average temperature of the sub-region. All indicators cover time periods that preceded the conflict (1994). The geographical and weather related indicators were originally at the district level. These district indicators were aggregated to sub-region means using sampling weights provided in the Nepal DHS.

The first stage results reported in Table 1 indicate a strong correlation between conflictinduced casualties and the proportion of a sub-region that is forested. This conclusion holds for when state-caused casualties and Maoist-caused casualties are measured separately and when they are combined. In regressions that include all six geographical and weather indicators, the coefficient on forest coverage is statistically significant. Forest cover remains significant when it is used as the only instrument in linear or binary form. Hence forest cover was selected as the instrument. To be able to implement a difference-in-difference methodology similar to that in Angrist and Kugler (2008), we converted forest coverage into a 0-1 indicator, where geographical sub-regions with forest-coverage exceeding the $75^{\text {th }}$ percentile value were classified 
as "more-forested", and sub-regions with forest-coverage below the $75^{\text {th }}$ percentile were classified as "less-forested." Since Nepal in general is quite heavily forested, a higher than average benchmark (such as the $75^{\text {th }}$ percentile value) was required to indicate regions that have relatively more cover. Note that these results are robust to transforming the dependent variable (total conflict-induced casualties) from levels into growth rates over time. Furthermore, our use of a categorical functional form for the first stage (as opposed to a linear functional form) is reaffirmed by a simple test that plots growth rates in casualties against a linear measure of forest cover. This test indicated that the relationship between growth rates and forest cover is not particularly linear; thus, a non-linear 0-1 form of the instrument was more appropriate in the first stage.

\section{Insert Table 1 Here}

Before discussing the data and results, it is helpful to present the strengths and weaknesses of the difference-in-difference methodology employed in this study. This method is appropriate when there are before-and-after time periods and two groups: one that is subject to the treatment, and another which is subject to all the other influences on the treatment group except the actual treatment itself. Of course, assignment into the treatment and control groups should not be systematically pre-determined. This research design is useful because it replicates a natural experiment in which one can isolate the effect of the treatment by comparing outcomes between the two groups over the two time periods. Since individuals in the treatment group are compared to individuals in the control group, and since the groups are comparable except for the fact that one receives the treatment while the other does not, the difference-in-difference methodology allows the researcher to isolate the unbiased effect of the treatment alone. This 
methodology also affords confidence that the effect measured is not contaminated by omitted variables and/or unobservable effects specific to either group.

As noted in Meyer (1995), the validity of the difference-in-difference method rests on demonstrating that the treatment and control groups had a similar distribution in outcomes in the before time-period. We implement this test before using the difference-in-difference method to evaluate the impact of the conflict on women's employment probabilities. In the context of our study, the "treatment" is conflict, and although women in general may work more when husbands have migrated or they are heads of their households because husbands are disabled, the application of the difference-in-difference method allows us to measure how much of the increase in women's labor force participation (over and above that which is generally true in similar circumstances) is due to conflict alone.

\section{Conflict and Women's Employment}

\section{$\underline{\text { Data and Descriptive Statistics. }}$}

This study's employment data come from the Nepal Demographic and Health Survey, a large nationally-representative sample of women aged 15-49 and the members of their households. We used the three most recently-available waves of the Standard DHS for Nepal, which cover 1996, 2001, and 2006. These waves correspond with the beginning, middle, and end of the civil war. The DHS surveys provide detailed information on the variables we required, including woman's employment status, education, age, marital status, region and terrain of residence, religion, and ethnicity; her husband's education and his presence in the household; and indicators of household composition, household access to electricity, and household amenities. Our working sample retains all ever-married women aged 15-49 with measured values for employment status and for the other indicators in the empirical analysis, leaving us with 
approximately 25,700 observations in the pooled sample. Note that the indicator for whether or not a woman is employed includes employment for cash earnings, in-kind payments, and nonremunerated work; the data do not allow us to separate these types of work. Among the employed women in the pooled data, a large proportion worked either for themselves or for their family (about 21,800 observations). We classified such women as self-employed and included separate regressions for the decision to be self-employed. ${ }^{2}$

Sample statistics in Table 2 indicate that a very high proportion of women in Nepal were employed throughout the period, and especially in 2001, when 83 percent of women were employed in some sort of job, paid or unpaid. Table 2 further indicates that over time, a growing proportion of women lived without their husbands, either due to the husband's migration or due to death, divorce, or separation. By 2006, almost one third of ever-married women lived without their husbands present in the household. The majority of women had no education in all three years, although this proportion declined sharply over the ten-year period, from 80 percent to 63

percent. Among other indicators, the vast majority of the sample lived in rural areas, with a greater tendency to live in Terai grasslands as opposed to the mountains and hills. Socioeconomic status indicators show some improvements during the 10 year period, with more households having access to electricity and household amenities such as improved flooring, radio, and television. Finally, the bulk of the sample claimed Hindu as their religion, with quite a diversity in ethnic groups.

Insert Table 2 Here

As demonstrated in Appendix Table 1, which reports the weighted percentages of the top five occupations for employed women across the period of analysis, the vast majority of employed women worked in agricultural self-employment, with the proportion of women 
engaged in this occupation peaking during the height of the conflict in $2001 .^{3}$ A very small percentage of employed women (1.7 percent in conflict-affected areas) worked in professional, technical, and managerial jobs at the height of the conflict, but this occupational category did not appear in the top five in 1996. If one considers this category to be relatively more maledominated, then this result provides some evidence that women in conflict-affected areas sought work in typically-male occupations, which could happen if more women were entering into the labor market to supplement income.

As noted above, the difference-in-difference methodology is appropriate in cases where the treatment and control samples are comparable in measured characteristics in the pretreatment time period. In order to ascertain that this comparability holds in the Nepal context, we calculated means of the individual and household indicators at the sub-region level for 1996 and then compared the sub-region means across the more-forested (conflict) and less-forested (nonconflict) classification. Recall that in the empirical approach, the "treatment" is conflict intensity as proxied by forest coverage. Results in Table 3 indicate that when conflict began in 1996, the more- and less-forested sub-regions had very similar characteristics in terms of women's status, household socioeconomic status, and household composition. Only one of the ethnic groups (Chhetri) showed a statistically significant difference. Hence overall, the treatment and control groups were comparable before conflict began.

Insert Table 3 Here

Women's Employment Decisions: Nä̈ve Probit Estimates

The next step is to examine the likelihood of a woman engaging in employment, conditional on an indicator for conflict as well as the full set of personal and household 
characteristics. We begin by specifying a standard labor supply equation for ever-married women of the following form:

$$
y_{i j t}=a+b S_{i j t}+c X_{i j t}+\mu_{j}+m_{t}+\vartheta_{i j t}--(1)
$$

where $i$ denotes a woman, $j$ denotes a sub-region, and $t$ denotes time. The dependent variable $y_{i j t}$ is a dummy that takes on the value 1 if the woman is employed and 0 otherwise. The notation $X_{i j t}$ is a set of individual and household characteristics that influence women's decisions to work, which include age, education, an indicator for more than two children of pre-school age, and other indicators of quality of the dwelling of the household (such as having electricity and improved flooring). ${ }^{4}$ The vector $S_{i j t}$ is a catch-all variable that indicates the effect of conflictrelated measures over and above the variables in $X_{i j t}$. The variable includes a normalized measure of the number of conflict deaths from 1996 to 2006 first in of itself, then restricted to households in which the husband has migrated, and households in which the woman is widowed, divorced, separated, or the head of her household for a reason other than the husband's migration. Finally, $\mu_{j}$ is a sub-region specific effect that is common to all individuals, $m_{t}$ is a time specific effect that is common to all individuals, and $\vartheta_{i j t}$ is a woman-specific idiosyncratic error term.

Given the binary nature of the dependent variable, we used a probit model to estimate the standard labor supply model in equation (1). These estimates are referred to as "naïve probits" since they do not condition for the endogeneity of casualties, husband's migration status, or whether women are widowed, divorced, separated, or heads of households due to a reason other than husband's migration. The naïve probits were used as a benchmark against which to compare estimates from the difference-in-difference approach, which conditions on the endogeneity of the 
conflict-related variables and thus allows us to estimate the causal effect of conflict on the likelihood of women's employment.

The naïve probit regression results are reported in Appendix Table 2. In all six columns, the conflict indicator is the number of conflict-related casualties by sub-region interacted with year dummies. In the table, 1996 is the excluded category - thus conflict interaction terms are measured with reference to the beginning of the civil war. Note that columns (3) and (4) depict effects specific to women in households with husbands who have migrated, while columns (5) and (6) depict effects specific to women who are widowed, separated, divorced, or designated as household heads because their husbands are incapacitated. All standard errors were corrected for clustering at the sub-region and year level.

The first column of Appendix Table 2 shows that as compared to when Nepal's civil war began, the probability of women's employment rose in sub-regions with greater conflict-related casualties in 2001 and 2006. The probability of self-employment in areas with more casualties was higher as well, although the coefficient in 2006 is measured with less precision. Focusing on the first two columns, older women were more likely to be employed, whereas some level of schooling exerted significant negative effects on employment probabilities. In column (3) for women whose husbands have migrated, employment probabilities were significantly larger in sub-regions with higher civil-war mortality in 2001 and 2006. However, there are no discernible effects of the conflict variables on self-employment probabilities in column (4). Coefficients in columns (5) and (6) for women whose husbands are absent for reasons other than migration suggest that employment probabilities are larger for these women in conflict areas in 2006 as compared to 1996, whereas self-employment probabilities are relatively higher in conflict areas 
in 2001 as compared to 1996. In general, the naïve probits exhibit little precision for the marginal effects of age and education in this sub-group.

In closing, the naïve probits serve to provide a qualitative benchmark - it is the difference-in-difference results discussed next that allow us to evaluate the causal impacts of conflict on women's employment likelihoods.

\section{Difference-in-Difference Approach}

The naïve probit estimates suffer from the fact that $S_{i j t}$ could be endogenous. To address this issue, we conducted a difference-in-difference approach that focuses on conflict-induced changes in women's employment as measured by the instrument for conflict. In implementing this approach, the standard labor supply equation for ever-married women was amended as follows:

$$
y_{i j t}=d+\Sigma_{s} \alpha_{0 s} F_{j s}+f X_{i j t}+\mu_{j}+m_{t}+\varepsilon_{i j t}-- \text { (2) }
$$

Where subscripts are as before, and the dependent variable is the same binary variable as in equation (1) for whether the woman is employed. The notation $X_{i j t}$ is the same set of exogenous individual and household characteristics, $\mu_{j}$ and $m_{t}$ are the sub-region specific effect and the time specific effect, and $\varepsilon_{i j t}$ is an idiosyncratic error term. The term of interest, $\Sigma_{s} \alpha_{0 s} F_{j s}$, represents the difference-in-difference term; it is measured as a set of interactions of the dummy variables for the conflict years and the dummy variable for relative forest cover; our instrument. In the estimations, the coefficients on the interaction terms (once they are converted into marginal probabilities) are interpreted as the marginal effects of Nepal's conflict on the likelihood of women being employed.

This difference-in-difference equation was estimated using a set of probit models for the likelihood of employment. We ran models for the employment decision as well as the decision to 
become self-employed, and we ran models for the full sample and two sub-samples: women whose husbands had migrated, and women who were either widowed, separated, divorced, or living with an incapacitated husband. Table 4 reports the marginal probabilities. Column (1) indicates that women living in a conflict sub-region had an increased likelihood of becoming employed in 2001 and 2006, and the same is true of the decision to become self-employed. Both key difference terms in the first two columns for all women are positive and statistically significant at the .05 level or higher. The magnitudes of the coefficients indicate that compared to 1996 , the probability of employment was 0.098 higher for women in conflict areas in 2001, and 0.095 higher in conflict areas in 2006. Thus, there is some decline in 2006 compared to 2001, which is consistent with the fact that conflict peaked in the 2001-2002 time period. Effects are similar for self-employment in column (2), although the magnitudes of the coefficients are smaller.

\section{Insert Table 4 Here}

Table 4 further shows very similar results for the employment decisions of women whose husbands have migrated, as well as for the employment decisions of women who manage their households due to other reasons. These results support the added worker effect; in particular, the hardship associated with civil war served as a strong incentive for women to engage in employment. Interestingly, the coefficients on the conflict instruments in column (4) are measured with less precision, suggesting that women with husbands who had migrated were not more likely to be self-employed. ${ }^{5}$ Combined with the significant coefficients for overall employment in column (3), this result may reflect the high start-up costs of self-employment activities and is generally contrary to the notion that remittances may finance women's selfemployment opportunities. 
In comparing the difference-in-difference estimates to the naïve probit estimates in Appendix Table 2, the naïve probits appear to overestimate the effects of conflict in 2001 on employment and self-employment, and underestimate the effects of conflict in 2006 on employment and self-employment. Consequently, the differential effects between 2001 and 2006 for employment and self-employment in the naïve probits are positively biased. In contrast, given the difference-in-difference approach and the specification tests conducted below, Table 4's estimates represent the true differential effects between these years for employment and selfemployment for the full sample and the smaller sub-samples.

\section{Robustness Checks}

This closing section reports the results of various robustness checks for the main results. First, instead of using the forest coverage variable to directly instrument for conflict in the probit equations, we estimated marginal probabilities for the likelihood of employment using predicted values of conflict. This approach is consistent with a standard two-stage framework. This alternative set of estimations was conducted by constructing the predicted value for conflict in a first-stage regression, and then including the predicted value for conflict interacted with year dummies in a second stage regression. In the first stage, we regressed the total number of casualties on a linear version of the forest variable, and then generated a predicted value. This predicted value was converted into its categorical counter-part based on the 75th percentile

threshold. The categorical predicted variable was then interacted with year dummies and included in a second stage probit regression for employment likelihoods. A similar procedure was followed in an alternative set of first stage regressions which conditioned on forest coverage and other geographical variables, all in linear form. 
The second-stage marginal probability results for the likelihood of employment are found in Table 5. The standard errors in this table are bootstrapped to adjust for use of first-stage predicted values in the second-stage. The conclusions closely mirror those described for the main difference-in-difference results. In particular, the likelihood of engaging in employment increased for women in conflict-intense areas in 2001 and 2006, as compared to 1996. Furthermore, conditional on being employed, women were also more likely to engage in selfemployment if they lived in sub-regions with high levels of conflict.

\section{Insert Table 5 Here}

Another robustness check for the main results is to identify the impact of conflict on women's employment using instrumental variable regressions. This strategy was implemented by running a set of instrumental variable probit regressions for women's decisions to engage in employment and in self-employment. For each of these outcomes, we ran three models: the first model measured conflict as total mortality, the second model proxied for conflict as the proportion of husbands who had migrated at the year and sub-regional level, and the third model proxied for conflict as the proportion of women who managed their households due to death, divorce, separation, or incapacitation of their husbands at the year and sub-regional level. For each of these models, we instrumented for the conflict measure with the binary variable for more- or less-forest coverage interacted with a dummy variable that combined 2001 and $2006 .^{6}$

These results, which are reported in Table 6, indicate that when conflict is measured by total casualties or is proxied by husband's migration status, civil war strife increased the likelihood of women engaging in employment and in self-employment. As shown in columns (1) and (2), the coefficients on the interaction terms for conflict are relatively large, positive and statistically significant, supporting the hypothesis of an added worker effect in Nepal. 


\section{Insert Table 6 Here}

The third check of the main difference-in-difference results was a set of linear two stage least squares (TSLS) estimates for the likelihood of employment at the sub-region level. This strategy first entailed transforming all the variables into sub-region averages by year. We then ran a set of TSLS regressions for employment, using two alternative instruments for conflict: first, the linear version of forest coverage, and second, the binary version of forest coverage. In both cases, the instrument was interacted with the conflict year dummies to capture differential effects over time. In keeping with the structure of the previous estimations, the TSLS regressions measured conflict in three different ways: total mortality due to state and Maoist violence, the proportion of women with husbands who had migrated, and the proportion of women managing without their husbands due to his death, divorce, separation, or incapacitation. Table 7 reports these results. Overall, the table shows further support for the hypothesis of an added worker effect, especially by the end of the conflict in 2006. The instrumented conflict variable interacted with the 2006 year dummy is positive and statistically significant in four of the six estimations reported. For the two instances when the coefficient on this interaction term is negative or imprecisely measured, conflict is measured as women whose husbands had migrated. The negative and significant coefficient suggests that at the aggregated sub-regional level, there is some limited evidence that remittances may have reduced women's likelihood of employment, as documented in Lokshin and Glinskaya (2009).

\section{Insert Table 7 Here}

The fourth check of our difference-in-difference approach tests the robustness of the exclusion restriction. That is, we need to ensure that forest cover has no independent effect on the dependent variable and affects women's employment only through its effect on conflict. It is 
possible that forest cover may be associated with poverty and other determinants of women's shadow wages, thus the exclusion restriction might be invalidated. In order to test the validity of the exclusion restriction, interactions of year and all variables from the first stage (from Table 1) were included in the main difference-in-difference model for employment. We also included a measure of district-level poverty from a pre-conflict time period (1995-1996) to this specification. ${ }^{7}$ In keeping with the structure of Table 4, separate employment effects for women in households where the husband had migrated, and in households where women were widows or separated or heads of households due to the husband's incapacitation, were also estimated. If the exclusion restriction is violated, then the main results of the difference-in-difference model in Table 4 should disappear when we control for the additional variables. ${ }^{8}$

Upon re-estimating this modified version of the model, we found that the exclusion restriction is robust. The previous results continue to hold - if anything, marginal employment impacts for all women and for women whose husbands had migrated become larger and more significant. For widows, separated women, and women in households with disabled husbands, the 2006 results remain invariant. We lose some precision for the 2001 coefficients in this subgroup which, nonetheless, remain positive in sign. ${ }^{9}$

The final set of robustness checks dealt with testing for bias from two sources: selection bias due to migration, and bias arising from omitted variables and serial correlation. Note that migration was already well-entrenched, and the "remittance economy" of Nepal was wellestablished before the conflict began in 1996 (Seddon et al., 1998). Conflict, in of itself, did not cause migration to begin. It is true that civil war somewhat increased existing rates of displacement, but this increase occurred mainly in the far-western and mid-western regions of the country where the conflict tended to be more intense. Moreover, it was mainly men who 
migrated, leaving women, children, and the elderly behind to tend household land. Since we measure employment probabilities for women, the possibility of selection in the dependent variable is likely to be small. Finally, since our instrument (forest cover) picks up effects specific to regions from which migration may have occurred (these areas tend to be relatively heavily forested), any potential bias is likely to be conservative in terms of our estimates. If our estimates are influenced by migration, then given that remittances from male migrants reduce women's employment probabilities, correcting for selection bias from migration would make our current results larger and more significant.

This set of checks included two further tests for selection bias. First, selection bias would be evident if women whose husbands had migrated were systematically different in terms of their employment decisions as compared to women whose husbands had not migrated. To check for this source of bias, we re-ran the above set of specifications for the sub-sample of women whose husbands did not migrate. Upon doing so, we found that the results are substantively the same as those in the full sample. Note that Table 4 reports results for the sub-sample of women whose husbands had migrated and again, the results are comparable to those in the full sample. In the second additional check for selection bias, we included husband's migration status directly among the control variables of equation (2). ${ }^{10}$ Although this variable is statistically significant, the coefficients on our instruments remain positive and significant, indicating that even with a control for husband's migration status, the main results remain valid. These tests confirm that selection bias from migration does not contaminate the main results reported in Table 4 .

Next, we considered separate effects for employment decisions that excluded selfemployment and found the main results described earlier to be broadly consistent with this new specification as well. With the restriction to those who are non-self-employed, the marginal 
effects on our instruments remain positive in sign. However, we lose some precision in estimates given the small sample size. Finally to ensure that the results are not confounded by bias due to omitted variables and serial correlation, we included separate linear trends for each sub-region and found that if anything, our earlier results became even stronger in terms of precision. ${ }^{11}$

To summarize, the main difference-in-difference results in Table 4 indicate that women's employment probabilities increased substantially as a consequence of the conflict in Nepal. These estimates provide evidence for the existence of an added worker effect for Nepalese women. Additional robustness checks that used different empirical methodologies and alternative definitions of the conflict variable corroborated the main results. Hence these data offer strong empirical evidence that as a result of the decade-long civil strife in Nepal, women were more likely to work in order to support their households.

\section{Conclusion and Implications.}

Consistent with the frequent observation that war is development in reverse, the Nepalese "People's War" from 1996 to 2006 entailed thousands of casualties and injuries, as well as the destruction of health and education infrastructure and stagnation of the economy. The economic repercussions of the war weakened the country's social fabric as households and communities struggled to survive by resorting to coping mechanisms such as migration. Given the preponderance of men among the migrants, a growing number of women remained behind to carry on the work burdens on their farms and within their households. An important question raised by these changes is whether women were induced to engage in more employment (the added worker effect), or whether they withdrew their labor supply in response to factors such as remittances. 
This study's difference-in-difference strategy uncovered a strong added worker effect during Nepal's civil war: women who lived in areas of Nepal with high conflict intensity were likely to engage in more employment in relation to comparable women in regions of low conflict intensity. Similar trends are evident in the case of self-employment. The main results are robust to alternative measures of conflict intensity, sample composition, and estimation strategies. Note that aggregating the data to the sub-region level yielded some limited evidence for the idea that remittances discouraged women from engaging in employment.

It is useful to compare our estimates of the conflict-induced increases in women's employment and self-employment probabilities with increases in women's employment that might result from an economic shock such as the husband losing his job. Such a comparison would allow us to judge the relative size of the conflict shock against that of an economic shock, and provide a benchmark against which to measure the importance of conflict effects.

Estimates in the table of main results indicate that across all women, those with husbands who have migrated, and those who are widows, separated, divorced, or household heads due to husband's disability, employment probabilities are between 0.079 to 0.136 higher for women in conflict areas (comparing 2001 and 2006 to 1996, the year in which civil-strife began). In order to judge whether these effects are significantly different from the employment effects of an economic shock such as having a man in the house who is currently not working or has not worked in the last 12 months, we estimated counterparts of the main specifications, after replacing the instrument for conflict with indicators of whether a man in the home is currently not working or has not worked in the last year. This comparison is somewhat crude but is sufficient to provide a rough threshold. Results indicate that across all categories of women, the indicator for husband's unemployment has no statistically significant effect on employment or 
self-employment probabilities. The sole exception is for the last group of women (widows, separated, divorced, and household heads) who show employment effects from having a man not currently working similar in magnitude to those arising from conflict; however, these effects are only evident for 2006. This benchmark comparison indicates that conflict had substantially different effects on women's work probabilities as compared to the effect of a local economic shock such as job loss for a man in the home. Whereas the economic shock of an unemployed man in the home produced little to no impact on women's employment decisions, the Nepalese conflict had strong, positive, and significant effects on women's employment and selfemployment probabilities.

The results have important policy implications both for more immediate changes as well as longer-term strategies. In the aftermath of civil war, viable economic policies are required to address the concerns that originally contributed to instigating conflict. In the case of Nepal, such policies should be tailored towards reducing inequities between different factions. As noted in Ghani and Iyer (2010), aid agencies working in tandem with public institutions should concentrate on the quick creation of jobs, and aim first to fulfill the short-term needs of the affected populations. Other medium and long-term obligations could follow later.

The results of this study suggest that job creation would be especially useful for women in the aftermath of the civil war. To the extent that the government can use macro-level and industrial policies to promote the industrial sector, our results indicate that women's incentives in terms of employment have changed and they would be particularly receptive to new opportunities in industry. Such jobs would, in turn, have the potential to reduce poverty as well as income inequality among the poor and among the overall population (Acharya 2008). Targeted use of microfinance to support and incentivize women would further aid in ensuring 
food security and economic welfare. Depending on the types of activities in which women choose to engage, public provision of vocational training and dissemination of know-how on accounting and management practices would also be useful. Furthermore, public and nongovernmental institutions could play key roles by providing subsidies that facilitate the purchase of profit-enhancing new technologies, as well as support for the marketing and sale of products created by women-run businesses.

If supported with adequate enforcement of labor standards, well-paying jobs would contribute to women's ability to support their families with cash earnings, which could in turn improve women's sense of autonomy. That said, increased employment opportunities alone are not enough to assist women, particularly in a country such as Nepal where society places a heavier premium on men's than women's earnings potential. This argument is supported with findings in Allendorf (2007) that husbands appear to prioritize their wives' education rather than their wives' ability to generate cash earnings in intra-household decision-making processes. Moreover, Yabiku (2005) finds that while the marriage market placed value on school enrollment for both men and women, working for others was seen as a desirable attribute only for men in the marriage market.

The emphasis on women's education in Nepal relates closely to the long-term ramifications of the added worker effect documented in this study. Women in Nepal work long hours on average. With the added pressure to sustain their families during times of conflict, an inordinately high burden of work would have been placed on the shoulders of Nepalese women. Beyond the negative effects of the added work burden on women themselves, it is conceivable that this responsibility had consequences for child-welfare. For example, if increased hours of work for mothers result in girl children being withdrawn from school to help with chores and 
child-care, the stock of educated women in future cohorts will contract. This decline in schooling has important implications for women's relative labor market performance in future generations. Although it is outside the purview of this study to document patterns on child welfare and human capital formation, we draw attention to child schooling in order to outline spheres in which Nepal's public institutions can intervene to counteract future adverse effects of a detrimental war that has already been so costly on several fronts. 


\section{References Cited}

Acharya, Sanjaya. 2008. "Poverty Alleviation and the Industrial Employment of Women (The Case of Nepal)," Journal of International Development 20 (5): 670-85.

Allendorf, Keera. 2007. “Couples' Reports of Women's Autonomy and Health-Care Use in Nepal," Studies in Family Planning 38 (1): 35-46.

Angrist, Joshua, and Adriana Kugler. 2008. "Rural Windfall or a New Resource Curse? Coca, Income, and Civil Conflict in Colombia," Review of Economics and Statistics 90 (2): $191-215$.

Bhalotra, Sonia, and Marcela Umana-Aponte. 2010. “The Dynamics of Women's Labour Supply in Developing Countries,” IZA Discussion Paper No. 4879.

Bohara, Alok, Mitchell, Neil, and Mani Nepal. 2006. "Opportunity, Democracy, and the Exchange of Political Violence: A Subnational Analysis of Conflict in Nepal," Journal of Conflict Resolution 50 (1): 108-128.

Deraniyagala, Sonali. 2005. "The Political Economy of Civil Conflict in Nepal," Oxford Development Studies 33 (1): 47-62.

Dex, Shirley, Gustafsson, Siv, Smith, Nina, and Tim Callahan. 1995. "Cross-National Comparisons of the Labor Force Participation of Women Married to Unemployed Men,” Oxford Economic Papers 47(4): 611-635.

Do, Quy-Toan, and Lakshmi Iyer. 2010. "Geography, Poverty and Conflict in Nepal," Journal of Peace Research, forthcoming.

Finegan, T. Aldrich, and Robert A. Margo. 1994. "Work Relief and the Labor Force Participation of Married Women in 1940," Journal of Economic History 54 (1): 64-84. 
Ghani, Ejaz, and Lakshmi Iyer. 2010. "Conflict and Development - Lessons from South Asia," Economic Premise 31: 1-8.

Gujarati, Damodar N. 2003. Basic Econometrics. Fourth edition. New York: McGraw-Hill.

Informal Sector Service Center (INSEC). 2010. "No. of Victims Killed by State and Maoist in Connection with the 'People's War' Database." On-line Database. Available at http://www.insec.org.np.

Jones, Nicola, Holmes, Rebecca, Marsden, Hannah, Mitra, Shreya, and David Walker. 2009. "Gender and Social Protection in Asia: What Does the Crisis Change?" Background Paper for Conference on the Impact of the Global Economic Slowdown on Poverty and Sustainable Development in Asia and the Pacific, Overseas Development Institute.

Lokshin, Michael, and Elena Glinskaya. 2009. "The Effect of Male Migration on Employment Patterns of Women in Nepal," World Bank Economic Review 23 (3): 481-507.

Macours, Karen. 2010. "Increasing inequality and civil conflict in Nepal," Oxford Economic Papers 62 (4): 1-26.

Menon, Nidhiya. 2009. "Rainfall Uncertainty and Occupational Choice in Agricultural Households of Rural Nepal," Journal of Development Studies 45 (6): 864-88.

Meyer, Bruce. 1995. "Natural and Quasi-Experiments in Economics," Journal of Business and Economic Statistics 13 (2):151-161.

Ministry of Health and Population (Nepal), New ERA, and Macro International Inc (MHP/NE/MI). 2007. Nepal Demographic and Health Survey 2006. Kathmandu, Nepal: Ministry of Health and Population, New ERA, and Macro International Inc. 
Ministry of Health (Nepal), New ERA, and ORC Macro (MH/NE/ORC). 2002. Nepal Demographic and Health Survey 2001. Calverton, Maryland, USA: Family Health Division, Ministry of Health; New ERA; and ORC Macro.

Murshed, S. Mansoob, and Scott Gates. 2005. "Spatial-Horizontal Inequality and the Maoist Insurgency in Nepal" Review of Development Economics 9 (1): 121-34.

Parker, Susan W., and Emmanuel Skoufias. 2004. "The Added Worker Effect over the Business Cycle: Evidence from Urban Mexico,” Applied Economics Letters 11 (10): 625-30.

Pradhan, Ajit, Ram Hari Aryal, Gokarna Regmi, Bharat Ban, and Pavalavalli Govindasamy. 1997. Nepal Family Health Survey 1996. Kathmandu, Nepal and Calverton, Maryland: Ministry of Health (Nepal), New ERA, and Macro International Inc.

Prieto-Rodriguez, Juan, and Cesar Rodriguez-Gutierrez. 2003. "Participation of Married Women in the European Labor Markets and the "Added Worker Effect,"' Journal of SocioEconomics 32 (4): 429-46.

Ra, Sungsup, and Bipul Singh. 2005. "Measuring the Economic Costs of Conflict". Asian Development Bank: Working Paper Series No. 2.

Seddon, David, Gurung, Ganesh, and Jagannath Adhikari. 1998. "Foreign Labor Migration and the Remittance Economy of Nepal”. Himalayan Research Bulletin XVIII (2): 3 - 10.

Seddon, David, and Jagannath Adhikari. 2003. "Conflict and Food Security in Nepal". Kathmandu: Report to Rural Reconstruction in Nepal.

Sharma, Kishor. 2006. "The Political Economy of Civil War in Nepal," World Development 34 (7): 1237-53.

Sharma, Hari Bhakta, and Tika Ram Subedy (eds). 1994. Nepal District Profile. Kathmandu: National Research Associates. 
World Bank. 2004. "Social Change in Conflict-Affected Areas of Nepal," Social Development Notes: Conflict Prevention \& Reconstruction 15: 1-4.

Yabiku, Scott T. 2005. "The Effect of Non-family Experiences on Age of Marriage in a Setting of Rapid Social Change," Population Studies 59 (3): 339-54. 
Table 1. First Stage Results for Conflict Intensity, Nepal DHS, 1996-2006

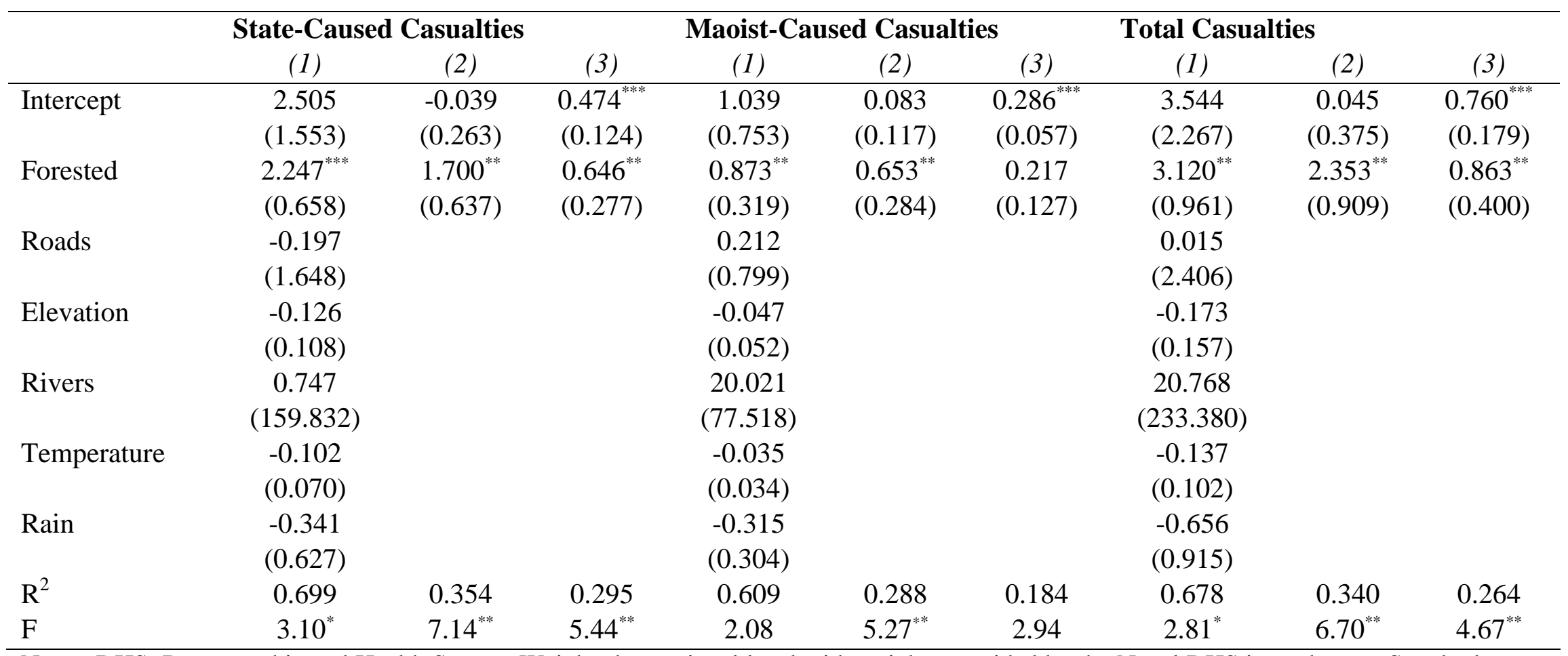

Notes: DHS=Demographic and Health Survey. Weighted to national level with weights provided by the Nepal DHS in each year. Standard errors in parentheses. The notation ${ }^{* * *}$ is $\mathrm{p}<0.01,{ }^{* *}$ is $\mathrm{p}<0.05,{ }^{*}$ is $\mathrm{p}<0.10$. Model (1) includes each regressor as linear variables; Model (2) includes only forested as a linear variable; and Model (3) includes only forested as a binary variable. All regressions have 15 observations at the sub-region level.

Source: Authors' calculations based on MHP/NE/MI (2007), MH/NE/ORC (2002), and Pradhan et al. (1997). 
Table 2. Women's Status and Household Factors, Nepal DHS, 1996-2006

\begin{tabular}{|c|c|c|c|c|c|c|}
\hline & 1996 & & 2001 & & 2006 & \\
\hline & Unweighted $N$ & $\begin{array}{c}\text { \% of Sample, } \\
\text { Weighted }\end{array}$ & Unweighted $N$ & $\begin{array}{c}\text { \% of Sample, } \\
\text { Weighted }\end{array}$ & Unweighted $N$ & $\begin{array}{c}\text { \% of Sample } \\
\text { Weighted }\end{array}$ \\
\hline Overall Sample & 8373 & 100.0 & 8719 & 100.0 & 8632 & 100.0 \\
\hline \multicolumn{7}{|l|}{ Basic indicators of women's status } \\
\hline \multicolumn{7}{|l|}{ Employed } \\
\hline Yes & 6634 & 77.3 & 7341 & 82.9 & 6481 & 73.6 \\
\hline No & 1739 & 22.7 & 1378 & 17.1 & 2151 & 26.4 \\
\hline \multicolumn{7}{|l|}{ Husband Gone } \\
\hline Yes & 1747 & 20.8 & 2096 & 25.0 & 2657 & 29.7 \\
\hline No & 6626 & 79.2 & 6623 & 75.0 & 5975 & 70.3 \\
\hline \multicolumn{7}{|l|}{ Education } \\
\hline No schooling & 6689 & 80.0 & 6265 & 72.0 & 5371 & 62.6 \\
\hline Some or all primary school & 890 & 11.0 & 1272 & 14.8 & 1461 & 16.8 \\
\hline Some secondary school & 537 & 6.3 & 832 & 9.3 & 1211 & 14.1 \\
\hline Completed secondary school + & 257 & 2.7 & 350 & 3.9 & 589 & 6.4 \\
\hline \multicolumn{7}{|l|}{ Literate } \\
\hline Yes & 1802 & 20.9 & 3134 & 35.3 & 4072 & 46.7 \\
\hline No & 6571 & 79.1 & 5585 & 64.7 & 4560 & 53.3 \\
\hline \multicolumn{7}{|l|}{ Age } \\
\hline age $<=20$ & 1275 & 15.5 & 1218 & 14.4 & 1061 & 12.1 \\
\hline $20<$ age $<=35$ & 4467 & 53.4 & 4744 & 54.2 & 4646 & 53.4 \\
\hline age $>35$ & 2631 & 31.2 & 2757 & 31.4 & 2925 & 34.5 \\
\hline \multicolumn{7}{|l|}{ Geographical indicators } \\
\hline \multicolumn{7}{|l|}{ Region } \\
\hline Eastern & 1666 & 22.9 & 2067 & 24.1 & 1916 & 21.4 \\
\hline Central & 2489 & 33.4 & 2388 & 32.1 & 2213 & 33.2 \\
\hline Western & 1584 & 19.6 & 1556 & 20.3 & 1683 & 19.4 \\
\hline Mid-Western & 1389 & 14.3 & 1141 & 13.7 & 1403 & 11.7 \\
\hline
\end{tabular}




\begin{tabular}{|c|c|c|c|c|c|c|}
\hline Far-Western & 1245 & 9.8 & 1567 & 9.8 & 1417 & 14.2 \\
\hline \multicolumn{7}{|l|}{ Terrain } \\
\hline Mountain & 1055 & 6.8 & 1188 & 6.9 & 1154 & 7.1 \\
\hline Hill & 3577 & 42.8 & 3241 & 41.4 & 3325 & 41.3 \\
\hline Terai grasslands & 3741 & 50.4 & 4290 & 51.6 & 4153 & 51.6 \\
\hline \multicolumn{7}{|l|}{ Urban } \\
\hline Yes & 946 & 8.4 & 1153 & 9.6 & 2279 & 14.8 \\
\hline No & 7427 & 91.6 & 7566 & 90.4 & 6353 & 85.2 \\
\hline \multicolumn{7}{|l|}{ Socioeconomic status indicators } \\
\hline \multicolumn{7}{|l|}{ Husband's education } \\
\hline No schooling & 3367 & 40.7 & 3131 & 37.3 & 2182 & 26.2 \\
\hline Some or all primary school & 1901 & 22.0 & 2184 & 24.8 & 2349 & 27.6 \\
\hline Some secondary school & 1625 & 19.4 & 2050 & 22.8 & 2458 & 28.2 \\
\hline Completed secondary school + & 1480 & 17.9 & 1354 & 15.1 & 1643 & 17.9 \\
\hline \multicolumn{7}{|l|}{ House has electricity } \\
\hline Yes & 1552 & 17.3 & 2068 & 22.5 & 4064 & 47.4 \\
\hline No & 6821 & 82.7 & 6651 & 77.5 & 4568 & 52.6 \\
\hline \multicolumn{7}{|l|}{ House has improved floor } \\
\hline Yes & 836 & 8.7 & 1171 & 12.0 & 1920 & 22.2 \\
\hline No & 7537 & 91.3 & 7548 & 88.0 & 6712 & 77.8 \\
\hline \multicolumn{7}{|l|}{ House has radio } \\
\hline Yes & 3522 & 40.7 & 3934 & 43.9 & 5229 & 60.0 \\
\hline No & 4851 & 59.3 & 4785 & 56.1 & 3403 & 40.0 \\
\hline \multicolumn{7}{|l|}{ House has television } \\
\hline Yes & 641 & 6.9 & 1245 & 13.4 & 2396 & 29.1 \\
\hline No & 7732 & 93.1 & 7474 & 86.6 & 6236 & 70.9 \\
\hline \multicolumn{7}{|c|}{ Household composition and ethnicity indicators } \\
\hline \multicolumn{7}{|l|}{ Two+ children under 5 yrs } \\
\hline Yes & 1102 & 13.0 & 960 & 11.1 & 740 & 8.0 \\
\hline No & 7271 & 87.0 & 7759 & 88.9 & 7892 & 92.0 \\
\hline
\end{tabular}




\begin{tabular}{lcccccc} 
Yes & 7343 & 87.5 & 7479 & 85.5 & 7537 & 85.6 \\
No & 1030 & 12.5 & 1240 & 14.5 & 1095 & 14.4 \\
Ethnic group & & & & & 1187 & 12.1 \\
Brahmin & 1159 & 13.6 & 1122 & 17.8 & 1899 & 18.4 \\
Chhetri & 1682 & 17.5 & 1829 & 17.8 & 173 & 5.6 \\
Occupational & 1248 & 14.6 & 1720 & 21.1 & 4373 \\
All other & 4284 & 54.4 & 4048 & 48.3 & 56.8 \\
\hline
\end{tabular}

Notes: Weighted to national level with weights provided by the Nepal DHS in each year.

Source: Authors' calculations based on MHP/NE/MI (2007), MH/NE/ORC (2002), and Pradhan et al. (1997). 
Table 3. Average Sub-Region Characteristics by More- and Less-Forested, Nepal DHS, 1996 (In percent)

\begin{tabular}{|c|c|c|c|}
\hline & $\begin{array}{c}\text { Less-Forested } \\
\text { Sub-Regions }\end{array}$ & $\begin{array}{c}\text { More-Forested } \\
\text { Sub-Regions }\end{array}$ & Difference \\
\hline \multicolumn{4}{|l|}{ Basic indicators of women's status } \\
\hline Employed & $\begin{array}{l}85.7 \\
(4.3)\end{array}$ & $\begin{array}{l}81.1 \\
(9.2)\end{array}$ & $\begin{array}{c}4.6 \\
(9.5)\end{array}$ \\
\hline Self-Employed & $\begin{array}{l}92.2 \\
(2.3)\end{array}$ & $\begin{array}{l}93.3 \\
(3.6)\end{array}$ & $\begin{array}{l}-1.1 \\
(4.9)\end{array}$ \\
\hline \multicolumn{4}{|l|}{ Education } \\
\hline No schooling & $\begin{array}{l}82.6 \\
(2.6)\end{array}$ & $\begin{array}{l}86.7 \\
(2.5)\end{array}$ & $\begin{array}{l}-4.1 \\
(5.3)\end{array}$ \\
\hline Some or all primary school & $\begin{array}{c}9.8 \\
(1.2)\end{array}$ & $\begin{array}{c}7.6 \\
(1.6)\end{array}$ & $\begin{array}{c}2.2 \\
(2.4)\end{array}$ \\
\hline Some secondary school & $\begin{array}{c}5.4 \\
(1.0)\end{array}$ & $\begin{array}{c}4.3 \\
(1.3)\end{array}$ & $\begin{array}{l}1.0 \\
(2.2)\end{array}$ \\
\hline Completed secondary school+ & $\begin{array}{c}2.2 \\
(0.7)\end{array}$ & $\begin{array}{c}1.4 \\
(0.9)\end{array}$ & $\begin{array}{c}0.8 \\
(1.4)\end{array}$ \\
\hline Literate & $\begin{array}{l}18.7 \\
(3.0)\end{array}$ & $\begin{array}{l}15.8 \\
(2.8)\end{array}$ & $\begin{array}{c}3.0 \\
(6.1)\end{array}$ \\
\hline \multicolumn{4}{|l|}{ Age } \\
\hline age $<=20$ & $\begin{array}{l}14.8 \\
(1.1)\end{array}$ & $\begin{array}{l}18.0 \\
(1.3)\end{array}$ & $\begin{array}{l}-3.2 \\
(2.3)\end{array}$ \\
\hline $20<$ age $<=35$ & $\begin{array}{l}52.6 \\
(0.7)\end{array}$ & $\begin{array}{l}52.4 \\
(3.1)\end{array}$ & $\begin{array}{c}0.1 \\
(1.9)\end{array}$ \\
\hline age $>35$ & $\begin{array}{l}32.6 \\
(0.9)\end{array}$ & $\begin{array}{l}29.5 \\
(1.8)\end{array}$ & $\begin{array}{c}3.1 \\
(1.9)\end{array}$ \\
\hline \multicolumn{4}{|l|}{ Geographical indicator } \\
\hline Urban & $\begin{array}{c}6.4 \\
(2.7)\end{array}$ & $\begin{array}{c}3.5 \\
(2.9)\end{array}$ & $\begin{array}{c}2.9 \\
(5.5)\end{array}$ \\
\hline \multicolumn{4}{|l|}{ Socioeconomic status indicators } \\
\hline No schooling & $\begin{array}{l}42.8 \\
(2.9)\end{array}$ & $\begin{array}{l}41.0 \\
(3.3)\end{array}$ & $\begin{array}{l}1.8 \\
(6.0)\end{array}$ \\
\hline Some or all primary school & $\begin{array}{l}24.0 \\
(1.8)\end{array}$ & $\begin{array}{l}24.5 \\
(3.3)\end{array}$ & $\begin{array}{l}-0.5 \\
(3.9)\end{array}$ \\
\hline Some secondary school & $\begin{array}{l}18.5 \\
(1.2)\end{array}$ & $\begin{array}{l}19.3 \\
(2.3)\end{array}$ & $\begin{array}{l}-0.7 \\
(2.6)\end{array}$ \\
\hline Completed secondary school+ & $\begin{array}{l}14.6 \\
(1.9)\end{array}$ & $\begin{array}{l}15.2 \\
(1.8)\end{array}$ & $\begin{array}{l}-0.6 \\
(3.9)\end{array}$ \\
\hline House has electricity & $\begin{array}{l}15.1 \\
(3.8)\end{array}$ & $\begin{array}{c}5.8 \\
(5.1)\end{array}$ & $\begin{array}{c}9.2 \\
(7.9)\end{array}$ \\
\hline
\end{tabular}


House has improved floor

8.2

(2.0)

House has radio

House has television

Household composition and ethnicity indicators

Two+ children under $5 \mathrm{yrs}$

Religion is Hindu

Ethnic group

Brahmin

Chhetri

Occupational

All other
39.8

(2.4)

5.0

(2.2)

13.1

(1.3)

86.3

(3.5)

14.2

(1.8)

20.1

(4.4)

17.8

(4.1)

47.9

(7.9)
3.5

(3.0)

42.3

(4.6)

2.7

(2.4)

15.5

(6.1)

97.2

(2.5)

11.0

(2.6)

43.1

(13.3)

15.6

(5.6)

30.3

(20.8)
4.7

(4.1)

$-2.5$

2.4

(4.6)

$-2.4$

$-10.9$

(7.0)

3.2

(3.8)

$-23.0^{* * *}$

(10.6)

2.2

(8.5)

17.6

(18.2)

Notes: Weighted to national level with weights provided by the Nepal DHS in 1996. Standard errors in parentheses. The notation ${ }^{* * *}$ is $\mathrm{p}<0.01,{ }^{* *}$ is $\mathrm{p}<0.05,{ }^{*}$ is $\mathrm{p}<0.10$.

Source: Authors' calculations based on MHP/NE/MI (2007), MH/NE/ORC (2002), and Pradhan et al. (1997). 
Table 4. Marginal Probabilities for Likelihood of Employment, Nepal DHS, 1996-2006

\begin{tabular}{|c|c|c|c|c|c|c|}
\hline & \multicolumn{2}{|c|}{ All Women } & \multicolumn{2}{|c|}{ Women with Husbands Migrated } & \multicolumn{2}{|c|}{ Widow/Sep/Div/HH Head } \\
\hline & Employed & Self-Employed & Employed & Self-Employed & Employed & Self-Employed \\
\hline \multicolumn{7}{|c|}{ Interaction Terms (reference=conflict_1996) } \\
\hline \multirow[t]{2}{*}{ Conflict_2001 } & $0.098^{* *}$ & $0.063^{* * *}$ & $0.134^{* *}$ & 0.001 & $0.099^{* *}$ & $0.149^{* * *}$ \\
\hline & $(0.032)$ & $(0.010)$ & $(0.032)$ & $(0.018)$ & $(0.023)$ & $(0.012)$ \\
\hline \multirow[t]{2}{*}{ Conflict_2006 } & $0.095^{* * *}$ & $0.046^{* * *}$ & $0.136^{* * *}$ & -0.013 & $0.079^{*}$ & $0.090^{*}$ \\
\hline & $(0.016)$ & $(0.012)$ & $(0.017)$ & $(0.020)$ & $(0.029)$ & $(0.031)$ \\
\hline \multicolumn{7}{|l|}{ Education (reference $=$ no schooling) } \\
\hline \multirow[t]{2}{*}{ Some or all primary school } & $-0.024^{* * *}$ & $0.025^{* * *}$ & $-0.041^{* *}$ & $0.034^{* * *}$ & -0.016 & $0.079^{* * *}$ \\
\hline & $(0.009)$ & $(0.008)$ & $(0.017)$ & $(0.009)$ & $(0.031)$ & $(0.020)$ \\
\hline \multirow[t]{2}{*}{ Some secondary school } & $-0.054^{* * *}$ & 0.013 & $-0.063^{* *}$ & $0.020^{*}$ & -0.031 & -0.062 \\
\hline & $(0.013)$ & $(0.012)$ & $(0.028)$ & $(0.010)$ & $(0.039)$ & $(0.061)$ \\
\hline \multirow[t]{2}{*}{ Completed secondary school+ } & $-0.076^{* * *}$ & $-0.325^{* * * *}$ & $-0.153^{* * *}$ & $-0.365^{* * *}$ & -0.052 & -0.043 \\
\hline & $(0.021)$ & $(0.043)$ & $(0.049)$ & $(0.054)$ & $(0.048)$ & $(0.078)$ \\
\hline \multicolumn{7}{|l|}{ Age $($ reference $=$ age $<=20)$} \\
\hline \multirow[t]{2}{*}{$20<$ age $<=35$} & $0.109^{* * *}$ & 0.004 & $0.086^{* * *}$ & 0.005 & $0.108^{* *}$ & $0.069^{* * *}$ \\
\hline & $(0.016)$ & $(0.011)$ & $(0.027)$ & $(0.012)$ & $(0.047)$ & $(0.032)$ \\
\hline \multirow[t]{2}{*}{ age $>35$} & $0.146^{* * *}$ & $0.038^{* * * *}$ & $0.128^{* * * *}$ & 0.016 & $0.110^{*}$ & $0.134^{* * *}$ \\
\hline & $(0.019)$ & $(0.011)$ & $(0.026)$ & $(0.016)$ & $(0.072)$ & $(0.045)$ \\
\hline Socioeconomic status & YES & YES & YES & YES & YES & YES \\
\hline Household composition & YES & YES & YES & YES & YES & YES \\
\hline Year and sub-region dummies & YES & YES & YES & YES & YES & YES \\
\hline Pseudo $\mathrm{R}^{2}$ & 0.194 & 0.207 & 0.236 & 0.275 & 0.174 & 0.202 \\
\hline $\mathrm{N}$ & 25,724 & 21,807 & 5,253 & 4,430 & 1,404 & 1,282 \\
\hline
\end{tabular}

Notes: Weighted to national level with weights provided by the Nepal DHS in each year. Standard errors, in parentheses, are clustered by regionyear. The notation ${ }^{* * *}$ is $p<0.01,{ }^{* *}$ is $p<0.05,{ }^{*}$ is $p<0.10$. In each regression the key difference-in-difference terms are the binary variable for moreor less-forested interacted with the year dummies. The Widow/Sep/Div/HH Head sub-sample excludes women whose husbands have migrated. Source: Authors' calculations based on MHP/NE/MI (2007), MH/NE/ORC (2002), and Pradhan et al. (1997). 
Table 5. Marginal Probabilities for Likelihood of Employment using Predicted Values, Nepal DHS, 1996-2006

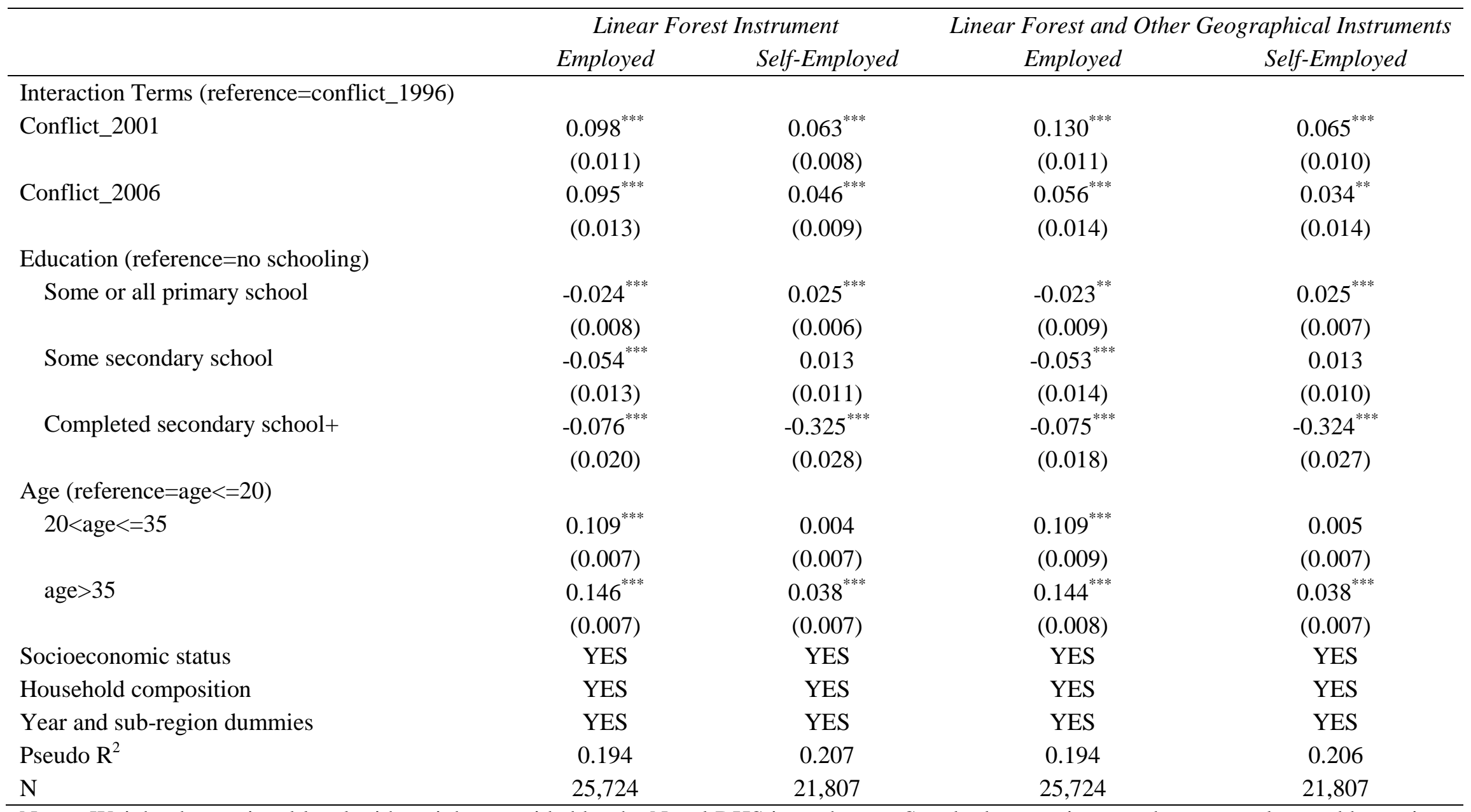

Notes: Weighted to national level with weights provided by the Nepal DHS in each year. Standard errors, in parentheses, are clustered by regionyear and bootstrapped to adjust for use of first-stage predicted values in the second-stage. The notation ${ }^{* * *}$ is $p<0.01,{ }^{* *}$ is $p<0.05,{ }^{*}$ is $p<0.10$. In each regression the conflict-year interactions are constructed as predicted values based on the linear forest instrument only (columns 1 and 2 ) and based on all the geographical variables in linear form (columns 3 and 4).

Source: Authors' calculations based on MHP/NE/MI (2007), MH/NE/ORC (2002), and Pradhan et al. (1997). 
Table 6. Instrumental Variable Probits for Likelihood of Employment, Nepal DHS, 1996-2006

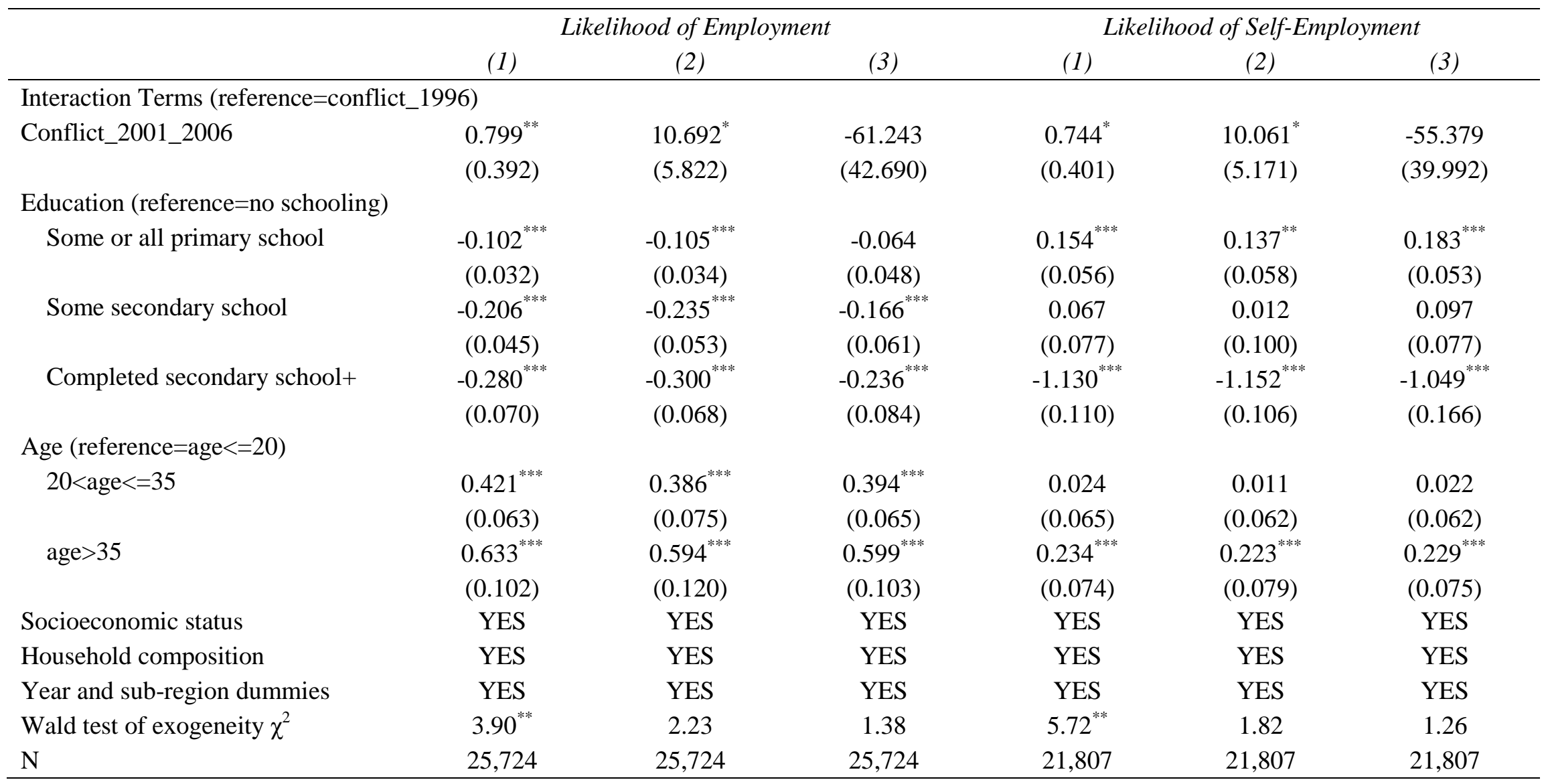

Notes: Weighted to national level with weights provided by the Nepal DHS in each year. Standard errors, in parentheses, are clustered by regionyear. The notation ${ }^{* * *}$ is $\mathrm{p}<0.01,{ }^{* *}$ is $\mathrm{p}<0.05,{ }^{*}$ is $\mathrm{p}<0.10$. In each regression we instrument for conflict with a binary variable for more- or lessforested interacted with a dummy that combines 2001 and 2006. Model (1) measures conflict as total mortality; Model (2) proxies for conflict as number of husbands migrated; and Model (3) proxies for conflict as number of women divorced, separated, widowed, or living with incapacitated husbands.

Source: Authors' calculations based on MHP/NE/MI (2007), MH/NE/ORC (2002), and Pradhan et al. (1997). 
Table 7. Two Stage Least Squares for Likelihood of Employment at the Sub-Region Level, Nepal DHS, 1996-2006

\begin{tabular}{|c|c|c|c|c|c|c|}
\hline & \multicolumn{3}{|c|}{ Linear Forest Instrument } & \multicolumn{3}{|c|}{ Binary Forest Instrument } \\
\hline & $(1)$ & $(2)$ & (3) & $(1)$ & $(2)$ & (3) \\
\hline \multicolumn{7}{|c|}{ Interaction Terms (reference $=$ conflict_1996) } \\
\hline Conflict_2001 & $\begin{array}{l}0.803^{*} \\
(0.457)\end{array}$ & $\begin{array}{l}-6.672 \\
(4.073)\end{array}$ & $\begin{array}{c}15.331 \\
(10.535)\end{array}$ & $\begin{array}{c}0.234 \\
(0.359)\end{array}$ & $\begin{array}{l}-4.359 \\
(3.017)\end{array}$ & $\begin{array}{c}4.486 \\
(5.210)\end{array}$ \\
\hline Conflict_2006 & $\begin{array}{l}0.091^{* * * *} \\
(0.021)\end{array}$ & $\begin{array}{c}-10.595^{*} \\
(6.298)\end{array}$ & $\begin{array}{l}2.432^{* * *} \\
(0.828)\end{array}$ & $\begin{array}{c}0.053^{* * *} \\
(0.018)\end{array}$ & $\begin{array}{l}-6.889 \\
(4.676)\end{array}$ & $\begin{array}{l}1.194^{* *} \\
(0.503)\end{array}$ \\
\hline \multicolumn{7}{|l|}{ Education (reference=no schooling) } \\
\hline Some or all primary school & $\begin{array}{c}0.255 \\
(0.706)\end{array}$ & $\begin{array}{c}2.328 \\
(1.965)\end{array}$ & $\begin{array}{l}-0.499 \\
(0.529)\end{array}$ & $\begin{array}{l}-0.505 \\
(0.549)\end{array}$ & $\begin{array}{c}1.282 \\
(1.437)\end{array}$ & $\begin{array}{c}-0.730^{* * *} \\
(0.321)\end{array}$ \\
\hline Some secondary school & $\begin{array}{c}0.903 \\
(0.594)\end{array}$ & $\begin{array}{l}10.249^{*} \\
(6.108)\end{array}$ & $\begin{array}{c}0.243 \\
(0.752)\end{array}$ & $\begin{array}{c}0.326 \\
(0.462)\end{array}$ & $\begin{array}{c}6.752 \\
(4.525)\end{array}$ & $\begin{array}{c}0.030 \\
(0.465)\end{array}$ \\
\hline Completed secondary school+ & $\begin{array}{l}-1.722 \\
(1.073)\end{array}$ & $\begin{array}{l}14.473 \\
(9.173)\end{array}$ & $\begin{array}{l}-1.581 \\
(1.875)\end{array}$ & $\begin{array}{l}-0.709 \\
(0.836)\end{array}$ & $\begin{array}{c}9.304 \\
(6.777)\end{array}$ & $\begin{array}{l}-0.488 \\
(1.085)\end{array}$ \\
\hline \multicolumn{7}{|l|}{ Age $($ reference $=$ age $<=20)$} \\
\hline $20<$ age $<=35$ & $\begin{array}{c}0.368 \\
(0.342)\end{array}$ & $\begin{array}{l}6.085^{*} \\
(3.452)\end{array}$ & $\begin{array}{c}0.140 \\
(0.529)\end{array}$ & $\begin{array}{c}0.262 \\
(0.264)\end{array}$ & $\begin{array}{c}4.136 \\
(2.551)\end{array}$ & $\begin{array}{c}0.205 \\
(0.350)\end{array}$ \\
\hline age $>35$ & $\begin{array}{l}1.346^{*} \\
(0.757)\end{array}$ & $\begin{array}{l}-0.671 \\
(1.029)\end{array}$ & $\begin{array}{c}0.881 \\
(1.103)\end{array}$ & $\begin{array}{c}0.632 \\
(0.586)\end{array}$ & $\begin{array}{c}-0.226 \\
(0.717)\end{array}$ & $\begin{array}{c}0.418 \\
(0.646)\end{array}$ \\
\hline Socioeconomic status & YES & YES & YES & YES & YES & YES \\
\hline Household composition & YES & YES & YES & YES & YES & YES \\
\hline Year and sub-region dummies & YES & YES & YES & YES & YES & YES \\
\hline Wald $\chi^{2}$ test & $3349^{* * *}$ & $467^{* * * *}$ & $1447^{* * *}$ & $5518^{* * *}$ & $1121^{* * *}$ & $3120^{* * *}$ \\
\hline $\mathrm{R}^{2}$ & 0.987 & 0.908 & 0.970 & 0.992 & 0.962 & 0.986 \\
\hline $\mathrm{N}$ & 43 & 43 & 43 & 43 & 43 & 43 \\
\hline
\end{tabular}


Appendix Table 1. Weighted Percentages of the Top Five Occupations for Employed Women by Less/More Forested Regions and Year, Nepal DHS, 1996-2006

\begin{tabular}{|c|c|c|c|c|c|}
\hline \multicolumn{6}{|c|}{ Less Forested Regions } \\
\hline \multicolumn{2}{|l|}{1996} & \multicolumn{2}{|l|}{2001} & \multicolumn{2}{|l|}{2006} \\
\hline Occupation & Weighted \% & Occupation & Weighted \% & Occupation & Weighted \% \\
\hline agriculture self-employed & 77.7 & agriculture self-employed & 90.1 & agriculture self-employed & 75.6 \\
\hline agriculture employee & 11.1 & sales & 4.4 & agriculture employee & 9.1 \\
\hline sales & 4.1 & skilled manual & 2.4 & sales & 5.6 \\
\hline skilled manual & 3.4 & prof., technical, managerial & 1.7 & skilled manual & 4.3 \\
\hline unskilled manual & 1.7 & unskilled manual & 0.5 & services & 2.2 \\
\hline \multicolumn{6}{|c|}{ More Forested Regions } \\
\hline \multicolumn{2}{|l|}{1996} & \multicolumn{2}{|l|}{2001} & \multicolumn{2}{|l|}{2006} \\
\hline Occupation & Weighted \% & Occupation & Weighted \% & Occupation & Weighted \% \\
\hline agriculture self-employed & 91.8 & agriculture self-employed & 95.1 & agriculture self-employed & 87.8 \\
\hline agriculture employee & 3.8 & sales & 2.1 & agriculture employee & 3.5 \\
\hline sales & 1.5 & prof., technical, managerial & 1.5 & sales & 3.3 \\
\hline unskilled manual & 1.1 & skilled manual & 0.8 & services & 1.7 \\
\hline skilled manual & 0.8 & services & 0.3 & prof., technical, managerial & 1.2 \\
\hline
\end{tabular}

Notes: Weighted to national level with weights provided by the Nepal DHS in each year. 
Appendix Table 2. Naïve Probits: Marginal Probabilities for Likelihood of Employment, Nepal DHS, 1996-2006

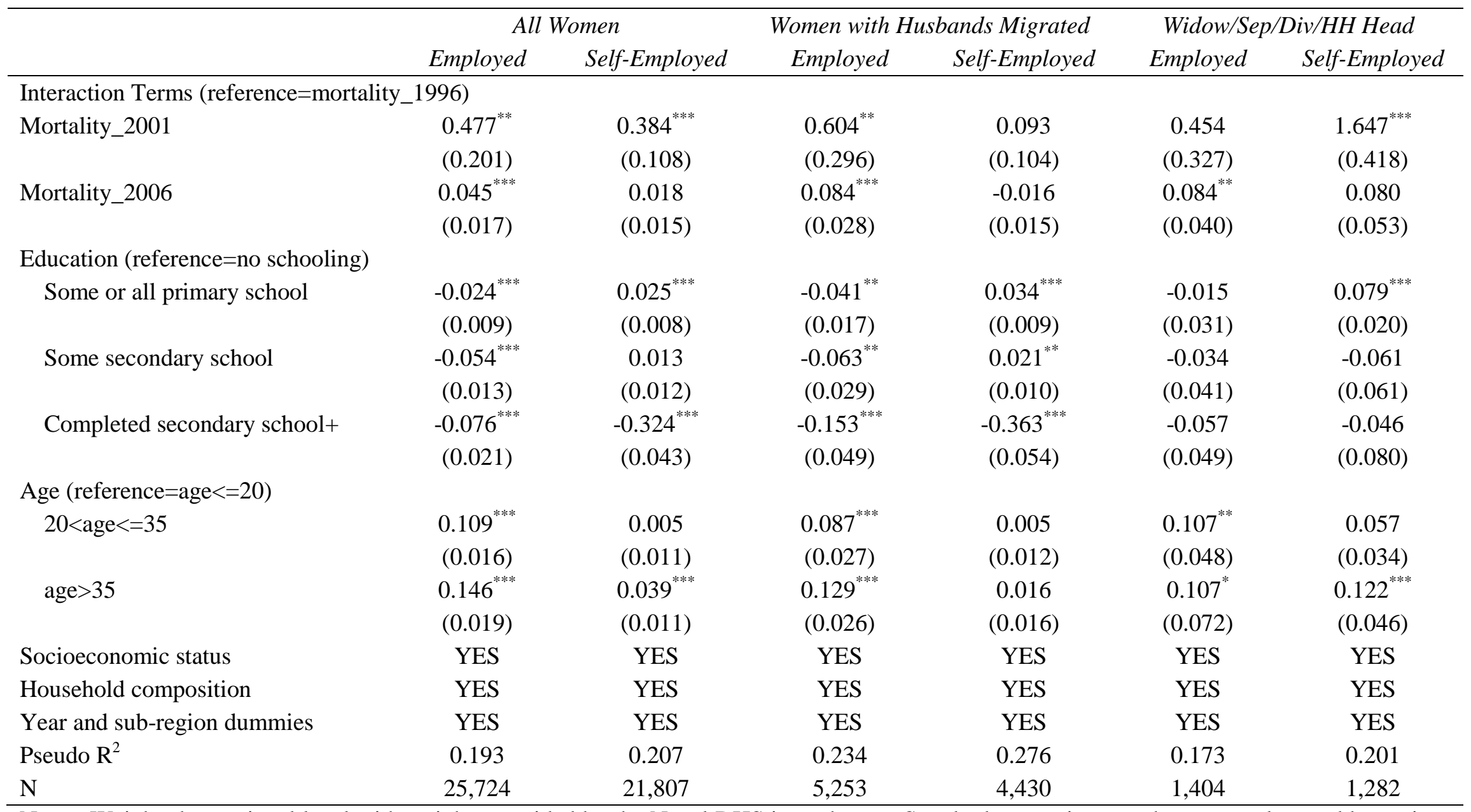

Notes: Weighted to national level with weights provided by the Nepal DHS in each year. Standard errors, in parentheses, are clustered by regionyear. The notation ${ }^{* * *}$ is $\mathrm{p}<0.01,{ }^{* *}$ is $\mathrm{p}<0.05,{ }^{*}$ is $\mathrm{p}<0.10$. In each regression the mortality-year interactions are presumed exogenous and we do not instrument for them. The Widow/Sep/Div/HH Head sub-sample excludes women whose husbands have migrated.

Source: Authors' calculations based on MHP/NE/MI (2007), MH/NE/ORC (2002), and Pradhan et al. (1997). 
Figure 1. Conflict-related deaths in Nepal, 1996-2006

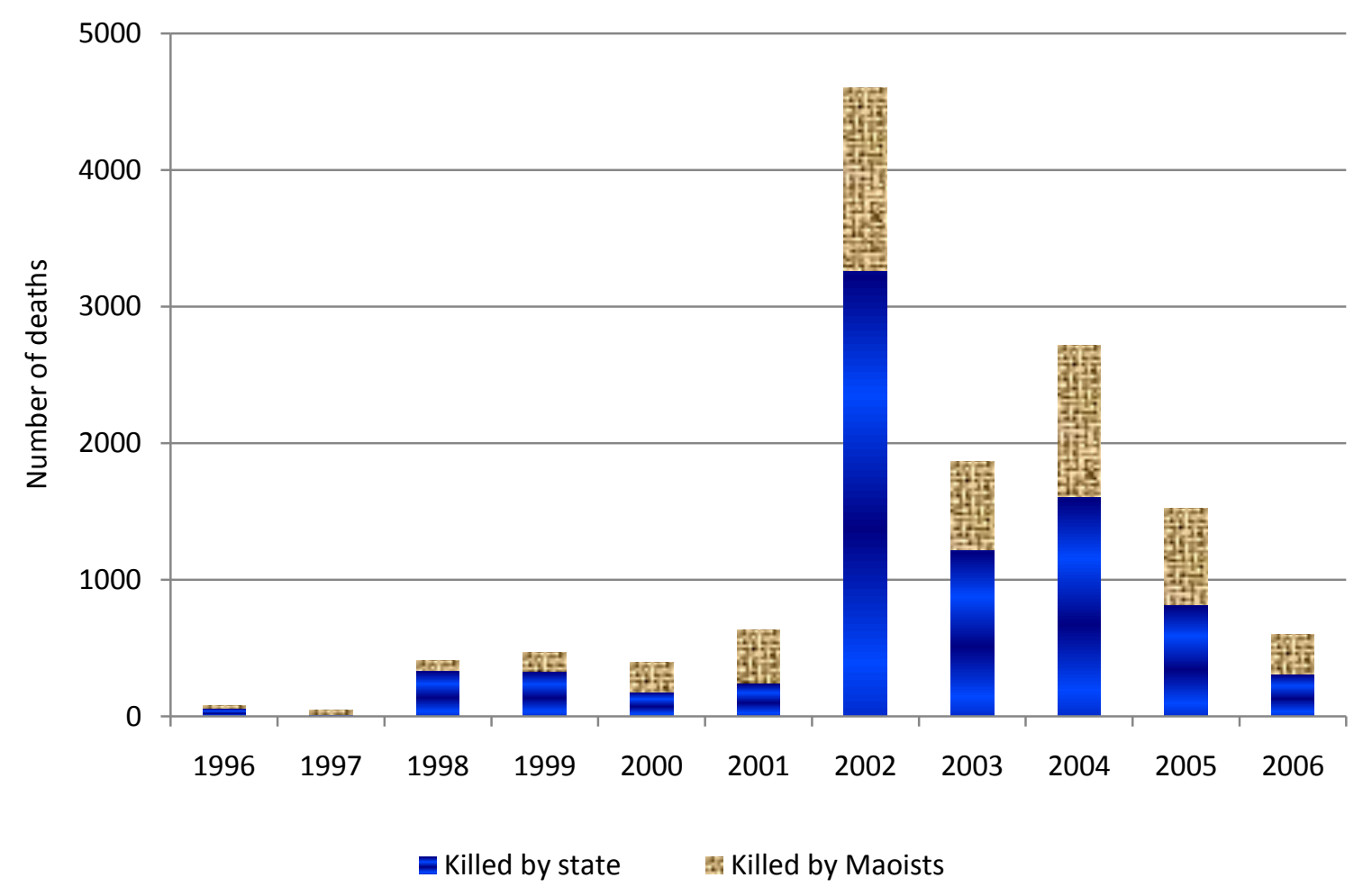

Source: Authors' calculations based on INSEC (2010). 
Figure 2. Indicators of Women Alone, Nepal DHS, 1996-2006

Panel A. Status of Husband's Presence

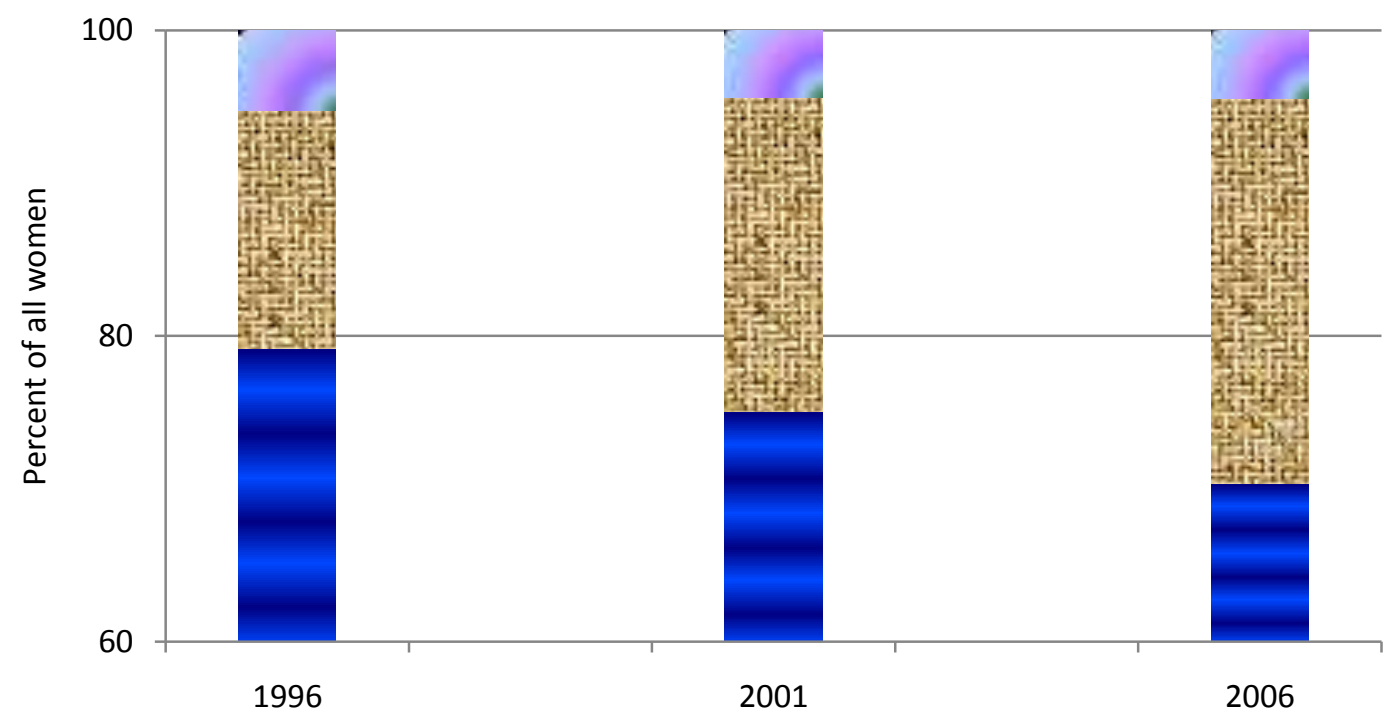

E Husband Present Husband Migrated Widowed, Separated, Divorced

Panel B. Status of Household Headship

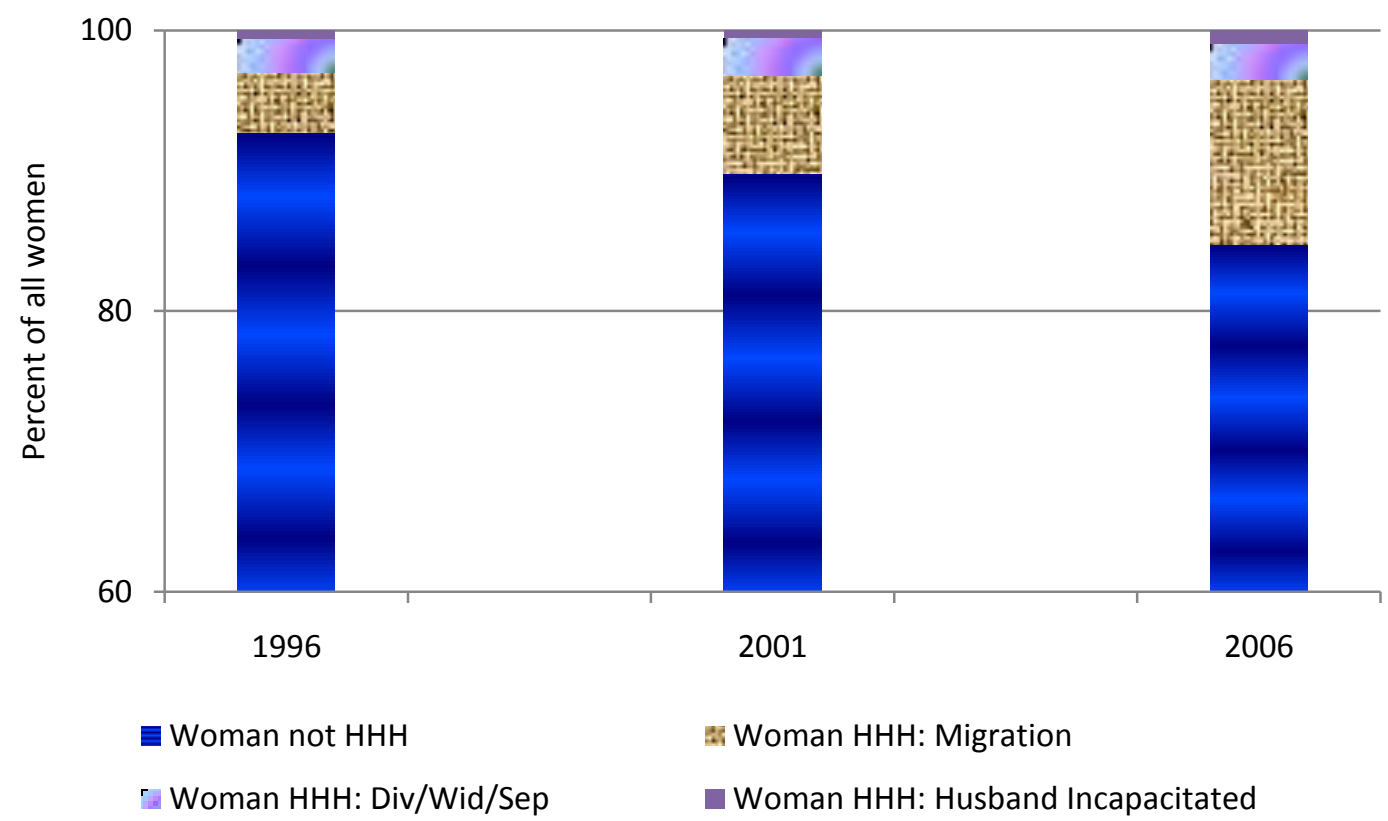

Notes: Weighted to national level with weights provided by the Nepal DHS in each year.

Source: Authors' calculations based on MHP/NE/MI (2007), MH/NE/ORC (2002), and Pradhan et al. (1997). 


\section{Endnotes}

1 In a separate set of regressions, we tested the predictive power of our instruments in explaining the growth in conflict intensity over the same time period. These regressions are not reported in the paper and are available upon request.

${ }^{2}$ We coded as self-employed those individuals who reported that they worked for themselves or for their family. The reference group is individuals who worked for someone else.

3 Note that the types of occupations do not differ much between less and more forested areas.

${ }^{4}$ This specification excludes the woman's potential wage, a variable that could also determine women's participation in the labor market (as in Dex et al. 1995 and Prieto-Rodriguez and Rodriguez-Gutierrez 2003 in their studies of the added worker effect). Including this variable would necessitate an instrumental variables technique to estimate the potential wage. Because the Nepal DHS does not include information on cash earnings in the three years of our analysis, we cannot follow this approach.

${ }^{5}$ Because the two sub-samples of women with husbands not present are not representative of all women, the estimates in columns 3-6 may be subject to selectivity bias. We address this issue by noting that male migration was already well-entrenched in Nepal before the conflict began. Furthermore, a specification check of the average proportion of husbands who had migrated regressed on the forest/year interaction terms and the full set of regressors at the year/subregional level finds no evidence of confounding effects from the instruments in 2001 or 2006 . A similar test for women who are widowed, separated, or household heads for a reason other than husband's migration also indicates that selection does not affect the results.

${ }^{6}$ We needed to combine the 2001 and 2006 dummies in order to achieve model convergence. 
${ }^{7}$ Another check involved using district-level means of a wealth index in the 1996 DHS data constructed from factor scores as another indicator of poverty. These results were similar to those from the district-level measure of poverty for a pre-conflict time period.

${ }^{8}$ Since more forested regions could be poorer, we included the forest variable directly in the difference-in-difference model as a final control for effects related to poverty. The forest variable is negative and significant in these runs, indicating that in more-forested areas, women are less likely to be employed. However, our main results as measured by the coefficients on the forest/year interaction terms remain positive and significant. Thus, even with the inclusion of the forest variable directly in the model, our previous results continue to hold.

${ }^{9}$ These regressions, including those with district means of the DHS 1996 wealth index from factor scores, are not reported in the paper. They are available upon request.

${ }^{10}$ This approach is similar to the strategy followed to address selection bias from migration in Angrist and Kugler (2008).

${ }^{11}$ These regressions, as well as those testing for selection bias described above, are not reported in the paper. They are available upon request. 